\title{
Inclusion or Exclusion? Emerging Effects of Middle-Class Citizen Participation on Delhi's Urban Poor
}

\author{
Poulomi Chakrabarti"
}

\begin{abstract}
1 Introduction
Although there has been much debate about the means of citizen participation, it is generally accepted that participatory democracy improves state responsiveness and creates better policies. Citizen participation allows voters to contribute to government decision-making beyond elections and can provide politically marginalised populations with a say in policy (Houtzager et al. 2003). As a result, citizen participation has gained the support of governments and international development agencies alike. The participatory budgeting practices developed in Porto Alegre in Brazil in the late 1980s, for example, have been replicated in cities worldwide.

In India the first initiative towards institutionalising citizen participation in governance was taken by the Delhi government through the Bhagidari programme in 2000. But unlike more conventional forms of participatory governance that target the working class and urban poor, Bhagidari was restricted to the middle-class parts of the city. Neighbourhood associations called Resident Welfare Associations (RWAs) represented citizens. Evaluations of the programme point towards improved urban services in neighbourhoods where Bhagidari was implemented. Based on the perceived success of Bhagidari, similar programmes have been initiated in other parts of the country. However, most studies so far have focused on the impact of the programme on urban services; the political impacts of the programme remain largely unexplored.
\end{abstract}

This article explores the ways in which the Bhagidari programme has influenced forms of demand making for the poor. Three factors seem to have shaped the impact of Bhagidari on the urban poor: a change in the relationship between RWAs and local political representatives due to the combination of Bhagidari and fiscal decentralisation; the emergence of a class identity of RWAs and their increasing influence on public policy; and the changing nature of RWAs and the government of Delhi within the larger political context. While I recognise that it may be too early to gauge the extent of these developments, it seems important to examine the potential impact of the incremental institutionalisation of citizen participation on existing channels of political representation for the poor.

The arguments presented here are based on 3.5 months of field research in Delhi, spread over the summer of 2006 and December 2006-January 2007. Section 2 places the Bhagidari programme in the context of attempts to decentralise urban governance in India. In Section 3 the basic features of the Bhagidari programme, the political logic for its introduction and neighbourhood associations' rise to power are outlined. Section 4 highlights the ways in which Bhagidari and middle-class activism impacted directly on the poor and their traditional channels of representation. Tentative conclusions are presented in Section 5.

\section{Participatory governance in India}

The Indian state sought to localise democracy through decentralisation in the early 1990s. The 73rd and 74th Constitutional Amendment Acts aimed to create local self-government in rural and urban areas, laying a framework to incorporate changes in the organisation, functions, and jurisdiction of local bodies. Success in implementing the acts however, varied between states and urban and rural areas. 
Ramanathan (2007) argues that the government largely ignored decentralisation in urban India instead focusing on panchayati raj institutions in rural areas. It was anticipated that creation of 'Ward Committees', comprising local political representatives and residents of one or more municipal wards, would allow for direct citizen participation in cities. In all but two states - West Bengal and Kerala, both of which have been run by strong communist governments for many years - decentralisation and particularly creation of ward committees has been difficult in urban India. The act's ambiguity over Ward Committees' constituency size and procedures for selecting members resulted in the creation of defunct ward committees in most cities (Kundu 2006). ${ }^{2}$ The ratio between citizens and their elected representatives for example is almost ten times higher in urban areas (Ramanathan 2007). There may be two possible reasons behind this variation: the concentration of different hierarchies of political representatives in urban areas allows very little political space for yet another level of government that could involve citizens; and the decentralisation policies in India were initiated by the federal government and were not a result of demands for greater autonomy by the state or local governments. For example, Harriss (2006: 9) emphasises that 'for most public administrators in India, the movement towards decentralisation seemed a grim necessity or a historical trend, rather than a positive good'.

In the capital city of New Delhi, the implementation of the act was especially problematic under the strong presence of federal government institutions, the State Assembly and the municipal government. The Ward Committees had as many as 1.25 million citizens per committee, which impeded proximity and accountability between the people and their elected representatives (Kundu 2006). During the same period, large cities in India saw a rise in neighbourhood associations, which some argue was an outcome of rapid growth generated after economic reforms in the early 1990s (Fernandes 2006; Chatterjee 2004). Movements by neighbourhood associations include the Porto Alegre-inspired experiment called Janagraha in Bangalore, the Advanced Locality Management programme in Mumbai, and RWAs in Chennai, Delhi and other cities. The Bhagidari programme sought to institutionalise citizen participation in governance by involving neighbourhood associations in local level decision-making but managed to do this without making any formal changes within the political structure, something the federal act was unable to achieve. The programme is largely seen as successful, as reflected by the number of national and international awards that it has received, including the UN Public Service Award in 2005. This perception of success has influenced governance policies both at state and national levels in India and led to the launching of similar programmes.

\section{Bhagidari and the rise of the RWAs}

The aim of Bhagidari (meaning 'collaborative partnership' in Hindi) was to provide a collective forum for government agencies and citizen groups to solve problems and manage public assets. It was expected that this exercise would empower citizens and develop their sense of ownership over government programmes (GNCTD 2006). Government agencies that participated in the programme included the government of Delhi and its departments, local municipalities (Municipal Corporation of Delhi and New Delhi Municipal Council), Delhi Development Authority, and utility agencies and companies (Delhi Jal Board and private power distribution companies). Citizen groups included RWAs, market and trader associations, industrial associations, village groups and nongovernmental organisations (NGOs). RWAs continue to be the main focus of the programme, its membership to Bhagidari growing from 20 in 2000 to more than 1900 in early 2007 (Joshi 2007). The Asian Center for Organisation Research and Development (ACORD), a private consulting firm that had previously been engaged in change management in large organisations like trade unions, implemented Bhagidari. ACORD organised workshops and meetings with government agencies and RWAs from 2000 to 2004.

The Delhi government has often been credited for progressive public policies, such as the conversion of all public transport to Compressed Natural Gas in 2002. It is not surprising that the Delhi government was the first to adopt participatory governance in India (Dikshit 2007). However, the specific reasons for the introduction of Bhagidari are important, including the support from both senior political leaders and bureaucrats. Bureaucrats supported the programme because Bhagidari is the brainchild of a senior civil servant in the Delhi administration. He conceptualised the programme based on the wider goals of participatory governance listed in the Congress Party 
manifesto and his team designed specific mechanisms for implementation (Regunathan 2007). But many programmes recommended by policy analysts cannot find political support. The reason why the Chief Minister not only adopted Bhagidari but also made it the centerpiece of her government can be explained by Delhi's unique institutional environment. In a city dominated by federal institutions, a high-profile and people-friendly programme like Bhagidari was the most visible means for the Chief Minister to publicise the achievements her government and exert authority. The large ongoing publicity campaign for the programme includes advertisements and notices in newspapers, billboards, public reports and even business cards of government officials that bear the Bhagidari logo alongside the 'Delhi government' insignia. Such publicity is significant as Bhagidari was implemented when the major opposition party, Bharatiya Janata Party (BJP), was in power at the Centre. Most of the activities of the Delhi government are now conducted under the rubric of Bhagidari.

The evolution of Bhagidari is paralleled with the changing role of RWAs in the city. During the initial years of the programme, the focus of Bhagidari was principally on RWAs. Bhagidari was heralded as one of the key achievements of the Delhi government (The Hindu 7 Oct/10 Oct/3 Dec 2003). Political observers even speculated that it would help the Congress Party-led government attract middle-class voters who traditionally supported the BJP (The Hindu 17 Mar/14 Nov/30 Nov 2003). The Congress Party did win the 2004 assembly elections and Bhagidari is credited as an important factor in the victory. But the rise of the RWAs ability to dominate public policy discourse began only after 2004 during the Congress Party's second term in office. RWAs arose after an important change in mode of delivery of public services - the privatisation of the stateowned electricity utility agency and consequent increase in user charges. RWAs from across the city formed horizontal networks to protest against the policy. These protests drew support from prominent citizens and celebrities who further attracted media attention. The role of the media was crucial in creating support for the protest and as a medium to bargain with government agencies. Under enormous public pressure, the government of Delhi was forced to revert to the old electricity rates. RWAs soon engaged in similar protests - against a proposal to privatise the water utility agency and another Master
$\mathrm{Plan}^{3}$ guideline to regularise illegal commercial establishments in the city. RWAs came to be identified as the key 'voice' of the citizen and their voice was often defined by their critical opinion of Delhi government policies, including the Bhagidari programme (The Hindu 31 Jul 2005). During the same period, Bhagidari drew criticism from within the state and central governments for failing to include large segments of the population, such as slum-dwellers and the poor (The Hindu 10 March 2006). Friction between RWAs and the Delhi government 'outside' the Bhagidari programme caused the Delhi government to shy away from RWAs, which resulted in a further decline of Bhagidari-related events like workshops and meetings (The Hindu 14 Dec 2005).

Meanwhile, mobilisation by RWAs following the protests led to the emergence of two large RWA umbrella organisations - the Delhi RWAs Joint Front (or Joint Front) and People's Action. The Joint Front primarily comprised of RWAs in the more affluent parts of South Delhi. Although they were highly critical of certain government policies, they saw themselves as one of the 'partners' in public decision making (Aggarwal 2007). The leaders in the Joint Front had been instrumental in shaping the implementation of the Bhagidari programme in its initial years. In contrast, People's Action had twice as many RWA members that spanned middle-class parts of the city. Their ideologies, however, vastly differed. Unlike Joint Front, People's Action argued that negotiations with the government was a means of co-option and refused to pay the increase in user charges until the Delhi government responded (Kaul 2006). Their means of protests were reminiscent of an opposition party. For example, they protested under the banner of 'Campaign Against Power Tariff Hike' and drew analogies with the ideas of civil disobedience/satyagraha and non-cooperation used during the non-violent freedom struggle against the British (The Hindu 3 Oct 2005, 7 May 2006). Backed by these ideologies, People's Action mobilised RWAs to contest the Municipal Elections in early 2007, a first for a large Indian city. This is interesting because middle-class associations, although culturally active, have traditionally been characterised by their distance from formal electoral politics.

\section{Bhagidari's impact on the urban poor}

A distinguishing feature of Bhagidari was that it was restricted to RWAs in the planned ${ }^{4}$ parts of the city. 
Although government officials recognise the limitations of this approach, the rationale behind the implementation process is based on two important concepts: scale and legality. Bhagidari was started as an experiment. RWAs were used as an entry point because it allowed the government to build on neighbourhood institutions that already existed at the lowest level. Although Bhagidari put RWAs in the spotlight, much of the growth of these associations took place in the mid-1980s as security concerns heightened in the capital following Indira Gandhi's assassination. ${ }^{5}$ RWAs are essentially neighbourhood management committees in apartment blocks or housing colonies to which the residents pay regular charges and in return oversee security and maintain common resources (Harriss 2005b). Government officials emphasised that it would have been difficult to organise deliberative meetings in slum settlements in the absence of formal representative associations like RWAs. Officials also expected that working with RWAs would be a learning experience for the government that would later help the programme expand to other areas in the city (Wadhera 2007, Koreth 2007, Regunathan 2007, Yadav 2006). Furthermore, development in unauthorised areas 'inevitably brings up issues about land tenure', which make it difficult to implement such programmes (Yadav 2006). So although government agencies continue to provide basic amenities such as water, street lighting and pavements in slums, they want to avoid negotiations that may result in the provision of land titles. The government's rationale is well summarised by Chatterjee (2004: 136): 'if squatters were to be given any kind of legitimacy by government authorities in their illegal occupation of public or private lands, then the entire structure of legally held property would be threatened'.

This distinction between 'planned' and 'informal' is key to understanding the variation in state-society relationship across different fragments of the Indian city. Chatterjee (2004: 35-7) draws a distinction between 'political society' and 'civil society'. Civil society, he argues, is founded on 'popular sovereignty and grants equal rights to citizens' (as taxpayers). Political society is the 'line connecting populations to governmental agencies pursuing multiple policies of security and welfare' (as voters). He argues that 'politics is often the only resource in a system which many deny the benefits of policy decisions or legal remedies to the poor'. Voting patterns for local municipal elections in Delhi support his argument, indicating that poor residents see political representatives as the main channel for making their voices heard (Baud et al. 2006). Similarly, Harriss (2005a) observes in his study of civic associations in Delhi that the urban poor most commonly solve problems through political party mediation while the middle class is more active in associational life like RWAs. Further, slum-dwellers often access their political representatives through local headmen called 'pradhans'. The title 'pradhan' is one that recognises someone who has some clout in a locality and who is able to exercise some influence (Harriss 2005a).

Edelman and Mitra (2006: 26) describe the process of bargaining between slum-dwellers and politicians as a client-patron relationship where tenure and basic amenities are exchanged for votes 'with the expectation of receiving large scale support at election time'. The pradhan is the person who gathers support for politicians by boosting attendance at rallies and assuring votes. While pradhans are accessible to all slum-dwellers, government officials are mostly accessed by the wealthy and the well connected (Rao et al. 2007). The key distinction between the urban poor and the middle class' access to the state is that the middle class uses bureaucratic and judicial channels as opposed to formal electoral politics (Harriss 2005a). This is partly because the middle class has better knowledge of the law and access to resources, but also because middle-class housing and occupations are more often 'formal' and 'legal' and become the basis for representation when outnumbered by the more politically active poor. This is reflected in voter turnout rates in the order of 35-40 per cent in middle-class areas as opposed to more than 80 per cent in poorer neighbourhoods and slums (Mazzarella 2006).

Middle-class residents are distant from formal electoral politics and local political representatives. In many neighbourhoods, especially in higher income areas, residents do not even know their local municipal councillor. When residents did approach politicians, residents were often frustrated with the clientelistic nature of politics that favours particular population groups in the ward. ${ }^{6}$ Importantly, Bhagidari brought RWA members from middle-class neighbourhoods and local political representatives to the same forum. Bhagidari workshops and meetings organised by the government of Delhi, particularly in the initial years of the programme, facilitated this process. The 
purpose of these workshops was to initiate dialogue and joint problem solving among key stakeholders RWAs and officials from government agencies and political representatives (GNCTD 2006). The institution of administrative mechanisms for better communication between RWAs and government agencies resulted from the workshops. 'Bhagidari Cells' and 'Nodal Officers' in each participating agency allowed RWAs access to the top tiers in these agencies directly. Since Bhagidari had the patronage of the Chief Minister, she took personal interest in the working of the 'Cells'. While these mechanisms were helpful to an extent in improving government agency responsiveness, they also resulted in a parallel system of governance that bypassed local political representatives, antagonising the relationship between RWAs and local politicians.

The Bhagidari programme and the developments surrounding the programme have influenced the relationship between government agencies, political representatives and citizen groups from the neighbourhood level to the level of the state. Although Bhagidari primarily targeted the middle class, the implications of the programme have extended to the urban poor. These implications, I suggest, have been shaped by three major factors: (1) a change in the relationship between RWAs and local political representatives (directly as a result of Bhagidari) and fiscal decentralisation in the municipal agency; (2) the class identity of RWA umbrella organisations and their ability to influence government decision making; and (3) the changing relationship between RWAs and the government of Delhi within the larger political context.

\subsection{Bhagidari and traditional forms of demand making}

As described earlier, Bhagidari provided a formal platform for RWAs and local political representatives to interact, in some instances for the first time. The system created a parallel governance track that undermined local politicians, resulting in tension between the two groups. During the same period, the Municipal Corporation of Delhi (MCD) had been pushing for greater decentralisation in its own administration. The councillors and Members of Legislative Assembly (MLAs) have traditionally been provided with constituency funds to spend for development-related work in their respective wards. The amount for this fund gradually tripled from £42,500.00 (Rs.35 lakhs) in 2002 to about
$£ 122,500.00$ (Rs.1 crore) in 2006. Municipal councillors and MLAs thus acquired greater executive powers within their jurisdictions. Their funds, that were originally only large enough for minor maintenance works, could now be used for more significant development. As a consequence of these two forms of decentralisation (Bhagidari and fiscal devolution), RWAs demanded more of local political representatives. In mega-cities like Delhi, where millions of dollars are pumped into large infrastructure projects, especially in recent years, the councillor's fund increasingly constitutes a minuscule proportion of the city's budget. But this could have a significant impact on service delivery for the urban poor because political representatives are the primary means through which the urban poor access the state. In the two wards studied, public spending for low-income neighbourhoods has remained more or less the same during 2002-7, but it has increased substantially for middle-class neighbourhoods, suggesting that the benefits of decentralisation disproportionately favour the middle class. For example, the expenditure on middle-class neighbourhoods in the South Delhi and North Delhi ward has increased by 27 per cent and 25 per cent respectively in a matter of only five years.?

Second, the recent dominance of RWA umbrella organisations has, to an extent, empowered RWAs at the neighbourhood level. People's Action mobilised RWAs to contest local municipal elections under the rationale that 'it was up to the middle class to clean up the dirty (vote-bank ${ }^{8}$ ) politics in the country that has marginalised the middle class' (Kaul 2006). RWAs contesting the elections belonged to a middle-class neighborhood with higher concentrations of professional and salaried class people, most of which had an antagonistic relationship with their local councillor following the Bhagidari programme. Although none of the RWA candidates won the $2007 \mathrm{MCD}$ elections, ${ }^{9}$ they did better than other independent candidates (The Hindu 9 April 2007). In addition, middle-class electoral participation in RWA-contested wards was higher than in comparable wards and previous years (The Hindu 20 April 2007). Since the primary reason behind the RWA's move toward formal politics is to safeguard middle-class interests and since formal electoral politics is the main channel through which the urban poor influences public policy, this development may crowd out poor voters and have adverse implications on service delivery for the poor. 


\subsection{Middle-class identity and the urban poor}

A change in public services triggered RWA mobilisation and class identity further contributed towards collective action. RWAs that led the protest were not only middle class in nature but also formed part of the salaried professional class. The issues they raised reflected and supported their middle-class identity and countered other social groups. This is exemplified by RWA umbrella organisation protests against affirmative action for backwards classes ${ }^{10}$ in higher learning institutes. Similarly, during the power hike case, the rationale for protest was not just the increase in user charges, but also the argument that the 'middle class should not be made to pay for others who form the "vote-bank" of political leaders', referring to electricity theft in informal settlements (The Hindu 18 Dec 2005). Joint Front and People's Action protested against regularisation of illegal commercial establishments in the city, many of which were owned by lower income populations (The Hindu 23 Oct 2006). RWAs from lower middleclass neighbourhoods criticised the Joint Front for being elitist and unaware of the 'ground realities and the unemployment prevailing in the Capital' (The Hindu 3 May, 28 March 2006). While political leaders regularised illegal shops on the grounds of securing the livelihoods of thousands of people, RWAs petitioned the courts against this policy on the rationale of 'planning, public interest and citizen's rights' (Civil Society 2006). About 90 per cent of the Public Interest Litigations filed by RWAs since 2000 (until May 2007) are regarding encroachments on public land and unauthorised construction (Office of the Registrar General, Delhi High Court 2007). Significantly, RWAs now strongly influence public policymaking and some of their self-interested demands are directed against the poor. Their access to the law and use of legal channels against informal settlements and occupations negatively impacts the poor.

At another level, the recent body of literature on the rise of middle class in India describes neighbourhood associations as hegemonic institutions that seek to re-define the use of public spaces by dislocating the urban poor from their visual proximity (Fernandes 2006; Chatterjee 2004). This mobilisation is explained as a sociological phenomenon as the middle class begins to mimic the lifestyle of the 'global city' and displaces subaltern ${ }^{11}$ groups in the process. While this theory might only hold true for certain elite neighbourhoods in the city, many middle-class neighbourhoods are increasingly becoming more exclusionary through the construction of boundary walls and gates. Many stand-alone developments by RWAs support this argument. For example, the Sundar Nagar RWA restricted vendors from entering their colony. Following a Public Interest Litigation by RWAs, the court directed the MCD to remove all slum clusters from the neighbourhood (Kundu 2006). Members of RWAs often equated slum settlements within and around their neighbourhoods with criminals (because they occupy land illegally) and stated that the removal of 'encroachments' was one of their association's objectives.

\subsection{Reaction to anti-Bhagidari}

As noted earlier, Bhagidari drew criticism from RWAs and within the government. The increasingly difficult relationship between RWAs and the Delhi government outside Bhagidari led the government to shy away from RWAs. Bhagidari was not discontinued since it was the most visible programme of the Delhi government, but the focus shifted to other sectors like education and health and most recently, to extending the programme to informal settlements. It will be interesting to watch this shift to informal settlements since the original reasons for not extending the programme to these settlements are still valid. The administration may be willing to extend the programme to informal areas because government officials' experience with the RWAs has prepared them for the more challenging task of working with associations of slum-dwellers. Also, this extension to informal settlements is timed immediately before the Assembly Elections in 2008 and slum-dwellers constitute the traditional support for the Congress Party in Delhi, the party currently in power. In fact, the Bhagidari programme was initially publicised in a large way only months before the last Assembly Elections in 2004. The focus is expected to be on education, vocational training and health. Spatially, the programme would focus on lowincome settlements where land titles are not disputed. The programme is currently in the planning stage but evaluation studies point towards improvement in services in neighbourhoods where Bhagidari was implemented.

\section{Conclusions}

Clearly, it is too early to judge whether Bhagidari is good or bad for the urban poor or even speculate on how significant the impacts on the poor may be in the 
future. The programme has strengthened the role of middle-class neighbourhood associations. These associations act in self-interest but in the process, their activities are often directed against the urban poor. The implications of Bhagidari and neighbourhood associations on the poor have been shaped by three factors: (1) a change in the relationship between RWAs and local political representatives combined with fiscal decentralisation; (2) the emergence of a class identity of RWA umbrella organisations and their ability to influence government decision making; and (3) the changing relationship between RWAs and the government of Delhi within the larger political context. Formal politics, law and media are the primary instruments that middle-class associations use to influence public policy.

Fiscal devolution within the local government and greater interaction between political representatives and RWAs as a result of Bhagidari has led RWAs to exert greater demands on local politicians. This has translated into an increase in public expenditure in middle-class neighbourhoods since the implementation of the programme. The administrative mechanisms instituted by Bhagidari further led to an antagonistic relationship between RWAs and local political representatives. As a consequence, some RWAs entered formal politics primarily on the grounds of 'safeguarding middleclass interests'. Both these developments could have significant impacts on the urban poor since the poor continue to use formal politics as the primary channel of accessing the state.

Activism by the middle class is defined by its class interest, which also has direct and indirect

\section{Notes}

* I would like to thank the Institute of Development Studies (IDS) for funding support. Many thanks to Anuradha Jodhi for comments and edits on many versions of this article. I am indebted to Judith Tendler and Bish Sanyal for supervising the original research on which this article is based. I would also like to thank Vijayendra Rao for his valuable feedback.

1 I mostly rely on qualitative research methods: both interviews and ethnographic tools. I conducted more than 50 interviews with current and retired government officials, political representatives, members of RWAs and heads of umbrella implications of the poor. Protests against affirmative action, increases in electricity rates (which RWAs argued was because of power theft by informal settlements) and the Master Plan guideline to regularise illegal commercial establishments (most of which are operated by low-income residents) are some examples. The role of the media, which the middle class dominates, is central to giving the protests a city (and even national) level presence thus adding to its political significance. Since middle-class occupations and housing are more often built on structures of legality, law becomes an important mechanism for the middle class to exert dominance over other social groups. This is exemplified by the use of Public Interest Litigations against informal settlements, both by individual RWAs in their neighbourhoods and RWA umbrella organisations against the Master Plan.

However, the larger democratic systems within which these institutions are embedded provide some leeway for the poor. Bhagidari drew criticism from within the government for failing to reach the majority of the city's population - the poor. The increasingly difficult relationship between RWAs and the Delhi government outside the programme led the government to shift its focus away from RWAs. Extension of Bhagidari to the informal settlements is a reflection of this shift. Although the success of the Bhagidari in informal settlements would depend on how the programme was implemented, the programme would bring the highest tiers in government closer to urban poor and would hopefully increase service delivery to those excluded from the current system.

associations of RWAs, leaders and residents of slums and informal settlements, academics and independent researchers and NGOs. Interviews with RWA members were concentrated in two municipal wards in North and South Delhi, respectively with the intention of choosing a sample representative of different socioeconomic backgrounds. I used government reports, documents, budgets and circulars provided by a host of local government departments to study the interaction of RWAs with these agencies. I relied heavily on newspaper and magazine articles to corroborate findings from interviews and fill in data gaps missed during fieldwork. In addition, I 
was on the email lists for two of the RWA umbrella organisations, which I used to trace the activities of the organisations. Finally, I have used published and unpublished articles, theses and books for literature review.

2 According to the Constitution of India, urban development is under the discretion of state governments. The implementation of the act, including constitution of ward committees, differs across states

3 The Master Plan is a statutory planning document that outlines the broad policies for the long-term (usually 10-20 years) development for the city.

4 Planned refers to either plotted (single family homes) or apartment-style housing developed through formal regulations/zoning guidelines. 'Unauthorised' or 'unplanned' development refers to housing privately developed without following the zoning regulations laid down by the Master Plan.

5 Indira Gandhi was assassinated by her two Sikh bodyguards in October 1984. After her death, anti-Sikh pogroms engulfed Delhi and other cities in northern India, resulting in over 2,700 deaths, mostly innocent Sikhs.

6 For example, many RWA members who I interviewed in North Delhi accused the councillor of nepotism and favouring the trader (Baniya) community to which he belonged. In South Delhi, RWA members blamed the councillor for supporting illegal encroachments in the neighbourhood since the poor formed the local politician's 'vote-bank'.

\section{References}

Aggarwal, Pankaj (2007) Secretary, Delhi Resident Welfare Association Joint Front. Interviewed in Delhi, 6 February

Baud, Isa; Shridharan, N. and Pfeffer, K. (2006) 'Mapping Urban Poverty for Local Governance in an Indian Mega-City: The Case of Delhi', paper presented at IDPAD Seminar on New Forms of Urban Governance in Indian Mega Cities, held in New Delhi, 20-21 June

Chatterjee, Partha (2004) The Politics of the Governed: Reflections on Popular Politics in Most of the World, New York: Columbia University Press

Civil Society (2006) 'Delhi residents put politicians on the mat', July-August

Dikshit, Sheila (2007) Chief Minister of Delhi. Interviewed in New Delhi, 7 February
7 This finding is based on analysis of ward-level municipal budgets from 2002-3 to 2006-7 onwards in two wards where I conducted fieldwork. I classify expenditure in different areas in the ward as 'middle-class' and 'low-income' neighbourhoods based on my knowledge of the wards.

8 Vote-bank politics is the practice of creating and maintaining vote-banks (a loyal bloc of voters from a single community, who consistently back a certain candidate or political formation in democratic elections) through divisive policies. As this brand of politics encourages voters to vote on the basis of narrow communal considerations, often against their better judgement, it is considered inimical to democracy.

9 Although RWAs contesting local elections was a new development in Delhi, the outcome of the election was largely decided by the issue of sealing commercial establishments. The protests and violence that followed the sealing worked against the Congress Party government. The antiincumbency vote went in favour of the major opposition party, the BJP.

10 Socially and economically backward classes that include Scheduled Castes, Scheduled Tribes and other Backward Castes are provided reservation in the public sector institutions as a means of affirmative action by the Constitution of India.

11 Subaltern refers to e-marginalised groups and lower classes in post-colonial literature.

Edelman, Brent and Mitra, Arup (2006) 'Slum Dwellers' Access to Basic Amenities: The Role of Political Contact, its Determinants and Adverse Effects', Review of Urban \& Regional Development Studies 18.1: 25-40

Fernandes, Leena (2006) India's New Middle Class: Democratic Politics in an Era of Economic Reform, Minneapolis: University of Minnesota Press

Government of NCT of Delhi (GNCTD) (2006) Delhi Human Development Report 2006, New Delhi: Oxford University Press

Harriss, John (2006) 'Middle-Class Activism and Poor People's Politics: Citizen-State Relations in Delhi and the Role of Civil and Political Organisations', paper presented at conference on Reassessing Civil Society, the State and Social Capital, Ullensvang Fjordhotell, Lofthus, Hardanger, Norway, 11-14 May 
Harriss, John (2005a) 'Political Participation, Representation and the Urban Poor: Findings from Research in Delhi', Economic and Political Weekly 40.11: 1047-54

Harriss, John (2005b) Middle Class Activism and Poor People's Politics: An Exploration of Civil Society in Chennai, London Working Paper Series 05-72, London: London School of Economics

The Hindu (2007) 'RWA candidates fared well in polls', 20 April

The Hindu (2007) 'RWAs make significant presence', 9 April

The Hindu (2006) 'RWAs feel let down by the court directions', 23 October

The Hindu (2006) 'Consumers start movement', 7 May

The Hindu (2006) 'Chaos at MCD office over sealing drive', 3 May

The Hindu (2006) 'New mixed land use policy evokes mixed response', 28 March

The Hindu (2006) 'Maken lashes out at Bhagidari', 10 March

The Hindu (2005) 'Power privatization review urged', 18 December

The Hindu (2005) 'Resentment clouds Sheila's 7 years in office', 14 December

The Hindu (2005) 'NGO launches power protest-II', 3 October

The Hindu (2005) 'Bhagidars turn the heat on Sheila Govt.', 31 July

The Hindu (2003) 'Sheila completes full term in office', 3 December

The Hindu (2003) 'Vote for our "positive message": Congress', 30 November

The Hindu (2003) 'Congress waits to reap Bhagidari harvest', 14 November

The Hindu (2003) 'Sheila still the best bet for Congress', 10 October

The Hindu (2003) 'Congress to face elections with full confidence: Sheila', 7 October

The Hindu (2003) 'Govt. set to derive mileage from Assembly Session', 17 March
Houtzager, Peter P.; Gurza Lavalle, Adrián and Acharya, Arnab (2003) Who Participates? Civil Society and the New Democratic Politics in São Paulo, Brazil, IDS Working Paper 210, Brighton: IDS

Joshi, Kulanand (2007) Deputy Secretary of the Chief Minister of Delhi. Interviewed in Delhi, 1 February

Kaul, Sanjay (2006) 'President, People's Action'. Interviewed in Delhi, 12 August/27 December

Koreth, George (2007) Chairman, Board of Governors, ACORD. Interviewed in Delhi, 5 February

Kundu, Debolina (2006) 'Decentralized Governance in Metro-cities: The Issue of Elite Capture with Special Reference to Delhi', paper presented at the IDPAD Seminar on New Forms of Urban Governance in Indian Mega Cities, held in new Delhi, 20-21 June

Mazzarella, William (2006) 'Middle Class', Department of Anthropology, University of Chicago, www.soas.ac.uk/csasfiles/keywords/ Mazzarella-middleclass.pdf (accessed 12 March 2007)

Office of the Registrar General, Delhi High Court (2007) List of Public Interest Litigations filed by RWAs from January 2000 to May 2007

Ramanathan, Ramesh (2007) 'Federalism, Urban Decentralization and Citizen Participation', Economic and Political Weekly 42.8: 674-81

Rao, Vijayendra; Woolcock Michael and Saumitra Jha (2007) 'Governance in the Gullies: Democratic Responsiveness and Leadership in Delhi's Slums', World Development 35.2: 230-46

Regunathan, S. (2007) Principal Secretary to the Chief Minister in 2000 (conceptualised Bhagidari programme). Interviewed in Delhi, 6 February

Wadhera, Kiron (2007) President and CEO, ACORD. Interviewed in Delhi, 5 February

Yadav (2006) Special Secretary to Chief Minister. Interviewed at Chief Minister's Office in Delhi, 19 July 